\title{
THE POLITICS OF ZAKAT MANAGEMENT IN INDONESIA The Tension Between BAZ and LAZ
}

\author{
Saidurrahman \\ IAIN Sumatera Utara, Medan - Indonesia
}

\begin{abstract}
The new Act of zakat management No. 23 Year 2011 has changed the position of private zakat management (LAZ; Lembaga Amil Zakat) which has no clear relationship with semi-governmental zakat management in the Act of Zakat Management No. 38 year 1999. This paper found that many debates arise especially on the position of private zakat management that has to work under the coordination of semi-governmental zakat management. Many data has shown that private zakat management has reached tremendous achievement compared to the semi-governmental zakat management. Based on this fact, this paper argues that zakat institutions in Indonesia needs to be managed properly without sacrificing the social capital i.e. the participation of private zakat management. This paper proposes that private zakat management needs to be given more spaces in optimizing the collecting and distributing zakat funds in Indonesia. The answer for this problem is building the regulator body for zakat management in Indonesia.
\end{abstract}

Keywords: Zakat, zakat management, government.

\section{Introduction}

Zakat is one of the five pillars of Islam, which has been made obligatory by Allah to each and every Muslim to carry out. The roles of zakat institution are not only to collect the zakat dues but also to redistribute the zakat funds to zakat recipients, so called asnâf. Zakat is collected from variety of sources such as individuals as well as corporate companies, while later on is distributed to the eight groups of recipients (asnaf) as prescribed in Holy Quran.

The concept of zakat exemplifies Islam's strong concern with social and economic justice. It serves as an equitable redistribution of 
wealth and income, which is enforced through moral obligation and fiscal measures. ${ }^{1}$ Zakat contains a moral imperative and is therefore obligatory because God in the Qur'an orders Muslims to contribute. ${ }^{2}$ Zakat originates from Arabic word which has two meaning. The first means "purity". From this meaning, zakat will purify properties from the rights of the poor. By setting aside certain amount of one's property, it will be purified. Zakat also means "development and increase" because it grants a fundamental right to the destitute and the needy. ${ }^{3}$ It is expected that if a Muslim pay zakat, he or she will be more prosperous than before. Thus, a rich person will not become poor when he or she pays zakat. ${ }^{4}$ Because zakat provides money to the poor, money will circulate more freely within the Muslim community, and will stimulate the economy in Muslim society. ${ }^{5}$ Therefore, zakat also contains the principle of social justice and wealth redistribution for the eight groups of recipients.

Many researches have proved the positive impact of Zakat on Social life of Muslim Society. ${ }^{6}$ However, the redistributive economic impact of zakat depends on how it is administered, especially with regard to collection and distribution. ${ }^{7}$ Unfortunately, the administration of zakat in Indonesia is not adequate, and therefore the full

1 Mohammed Ariff, "Introduction," in Mohamed Ariff (ed.), Islam and the Economic Development of Southeast Asia: The Islamic Voluntary Sector in Southeast Asia (Singapore: Institute of Southeast Asian Studies, 1991), p. 2.

2 G.C. Kozlowski, "Religious authority, reform, and philanthropy in the contemporary Muslim world," in W.F. Ilchman, S.N. Katz, \& E.L. Queen II (eds), Philanthropy in theworld's traditions (Bloomington: Indiana University Press, 1998), pp. 279-308.

${ }^{3}$ T. Khalidi, The Qur'an: A new translation (New York: Penguin Classics, 2008).

4 S. A. Siddiqi, Public Finance in Islam (Lahore, Pakistan: n.p., 1968), p. 28; M. A. Mannan, Islamic Economics: Theory and Practices (Cambridge: Hodder and Stroughton, 1986); Didin Hafidhuddin, Zakat Dalam Perekonomian Modern (Jakarta: Gema Insani, 2002).

5 Yusuf Al-Qaradawi, Figh az-Zakah (Beirut: Mu`assasat al-Risalah, 1997), pp. 37-38; Idem, Spektrum zakat dalam membangun ekonomi kerakyatan (Jakarta: Media Intelektual, 2005).

${ }^{6}$ M. Abdullah and Abdul Quddus Suhaib, "The Impact of Zakat on Social life of Muslim Society," Pakistan Journal of Islamic Research, Vol. 8 (2011).

7 Taufik Abdullah, "Zakeat Collection and Distribution in Indonesia," in Ariff (ed.), Islam and Economic Development, pp. 50-84. 
potential of zakat has not yet been realized. ${ }^{8}$ Data showed that the actual zakat funds in Indonesia was still less than 5 percent of its potential funds. ${ }^{9}$

The Indonesian government had promulgated a law of zakat management in 1999 under the Law Number 38. This law has been abrogated by the Law Number 23 Year 2011 regarding with Zakat Management in Indonesia. The replacement was made to revise certain aspects of the 1999 law, namely the position of BAZ vis-à-vis LAZ in zakat management. This article will examine the law, its background, and its impact on the existence of nongovernmental zakat collectors to portray the politics of non governmental Zakat Institution management in Indonesia.

\section{Literature Review}

Indonesia is the largest Muslim populated country in the world. $87 \%$ of 220 million people in Indonesia are Muslims. This comprised of about 191 million Muslims. From that figure, 40\% (76.5 million) are subject to pay zakat, whereas the rest are entitled to receive zakat. Ideally, the rich Muslims can financially support the poor using the instrument of zakat. Thus, zakat, as an instrument of Islamic social welfare, should become a source to improve social-economic welfare for Muslim society in Indonesia. This means that zakat are very potential to alleviate poverty and promote social well-being if zakat can be organized effectively. ${ }^{10}$ For that awareness, the scholarship on the issue of zakat management is increasingly abundant in recent years.

A.A. Miftah argued that zakat based fund has not yet contributed sufficiently to solving poverty problem in Indonesia. There are a number of possible factors contributing to this failure. One of them is the continuing practice of traditional management of zakat in which zakat funds are distributed by individual rich to the large number of poor Muslims in form of charity. Usually, the funds received by each poor person are enough only to support their basic needs for only a couple of days. Due to this problem, this paper proposed to redefine

\footnotetext{
${ }^{8}$ Bahtiar Effendy, Islam and the State in Indonesia (Singapore: Institute of Southeast Asian Studies, 2003), pp. 164-165.

9 Irfan Syauqi Beik et. al., "Economic Estimation and Determinations of Zakat Potential in Indonesia," IRTI Working Paper Series (09 October 2012), p. 2.

${ }^{10}$ M.D. Doa, Menggagas Pengelolaan Zakat oleh Negara (Jakarta: Nuansa Madani, 2005).
} 
the concept of zakat in the level of perception, law system, management and application. ${ }^{11}$

Other researcher, Zulkipli Lessy, discussed the development of zakat management to improve Islamic social welfare in Indonesia. Major issues in this paper are the elements of Islamic welfare efforts, the advancement of zakat institutions, and Muslims' misperceptions about zakat fitrah and zakat mal. Additionally, he discussed the role of the Indonesian government in regulating zakat and will highlight problems arising from the regulation. He highlighted the success story of Rumah Zakat Indonesia (RZI), a private institution of zakat collection founded to improve Islamic social welfare through its philanthropic activities. Because of its relative success compared to governmentinitiated zakat institution, the author suggested that the government and private zakat institutions should collaborate instead of competing with each other. ${ }^{12}$

In the similar vein, Irfan Syauqi Beik et.al., argued that the Government of Indonesia should consider zakat fund as one of financial sources for the country in addition to tax fund. The results show that total of all zakat potential in Indonesia from various sources is approximately 217 trillion rupiah. This number is equal to $3.4 \%$ of Indonesia's 2010 GDP. However, the real collection of zakat fund is still far away from the potential number. This showed that the collection and distribution of zakat fund is still in need to be improved continuously. ${ }^{13}$

Finally, Alfitri ${ }^{14}$ concluded that there is an urgent need of regulations that better facilitate the nongovernmental zakat institutions would maximize the mobilization of zakat funds and their immediate redistributive economic impact in Indonesia. The nongovernmental zakat institutions have the same potential for generating zakat funds as the semi-governmental collector bodies do. While some private zakat management institutions perform very well, the rest still need

11 A.A. Miftah, "Pembaharuan Zakat Untuk Pengentasan Kemiskinan di Indonesia," Jurnal Innovation, Volume VII, No. 14 (Juli-Desember 2008).

12 Zulkipli Lessy, "Zakat (Alms-Giving) Management in Indonesia: Whose Job Should It Be?," La Riba Jurnal Ekonomi Islam, Volume III, No. 1 (Juli 2009).

13 Beik, "Economic Estimation and Determinations of Zakat Potential in Indonesia".

14 Alfitri, "The Law of Zakat Management and Non-Governmental Zakat Collectors in Indonesia," The International Journal of Not-for-Profit Law, Volume 8, Issue 2 (November 2005). 
professional management and oversight. And this can be remedied if the enabling regulation is enacted and referred by all zakat management in Indonesia, both private and government initiated ones.

\section{The History of Zakat Management in Indonesia}

Zakat is an obligation of Muslims to give a specific amount of their wealth - with certain conditions and requirements. Zakat is "that portion of a man's wealth is designated for the poor". It is also defined as, "a compulsory levy imposed on Muslim so as to take surplus money or wealth from the comparatively well-to-do members of the Muslim Society and give it to the destitute and needy". ${ }^{15}$ As the definition implies, zakat is viewed by Muslims as a means of purifications and not just an obligation. Zakat plays an important role not only in the economy, but also in the moral and social well-being of a society. Morally, zakat promotes sharing of wealth and eliminates greed, whilst socially; it helps to reduce poverty within the community. ${ }^{16}$ As a result, wealth is widely distributed to all sections of the society and this, undoubtedly, encourages healthier economic environment as well as social cohesion. There are eight categories of people that are eligible to receive zakat including the poor, the needy, zakat worker (ami), the wayfarer, the heavily indebted, freedom of slaves, new converts to Islam, and the cause of Allah."17

Hassan $^{18}$ argued that based on the Islamic perspectives, poverty may be eliminated by using three distinct set of measures; i) positive measures, ii) preventive measures, and iii) corrective measures. One of the corrective measures of poverty eradication is through the payment of zakat. Wahid also underlined that zakat is one of the important pillars of Islamic faith that was not only instituted to increase the

15 Al-Qaradawi, Fiqh aæ-Zakah (Beirut: Mu`assasat al-Risalah, 1997), pp. 37-38; Sayyid Sabiq, Fiqh al-Sunnah (1991), p. 1.

16 T. E. Gambling, \& R. A. A. Karim, "Islamic and social accounting," Journal of Business Finance \& Accounting, 13, 1 (1986): pp. 39-50; M. Sulaiman, "The Influence of Riba and Zakat on Islamic Accounting," Indonesian Management and Accounting Review, 2, 2 (2003): pp. 149-167.

17 N. M. Nasir and A. Zainol, "Globalisation of Financial Reporting: an Islamic Focus," in Godfrey, J. M. and Chalmers, K. (eds), Globalisation of Accounting Standards (Cheltenham, UK: Edward Elgar, 2007), p. 262.

${ }_{18}$ M. K. Hassan, "An Integrated Poverty Alleviation Model Combining Zakat, Awqaf and Microfinance," Paper presented at Seventh International Conference - The Tawhidi Epistemology: Zakat and Waqf Economy, Bangi, Malaysia, 2010. 
welfare of the poor but also to serve as a means of economic growth and stability. Therefore, zakat is a compulsory payment on the part of Muslims as share to the poor, having a wide variety of economic and social ramifications. ${ }^{19}$

Based on traditional Islamic jurisprudence, the role of government is instrumental in the implementation of zakat in a Muslim country. The government is responsible for zakat collection and distribution. The government also has the authority to check individual Muslims to pay their zakat. This opinion is shared by all traditional schools of law in Islam. They justified this opinion on the practice by the Prophet Muhammad who during his lifetime collected and distributed zakat. In doing so, he also appointed zakat collectors and distributors to implement this sacred obligation. ${ }^{20}$

In early Indonesian history, mosques and madrasabs were institutions managing zakat. When Javanese Muslims paid zakat, the most notably usage of the fund was for building mosques and madrasabs as their religious educational institutions. ${ }^{21}$ During the Dutch era in Indonesia, religious leaders took part in collecting and distributing zakat. They used zakat funds for education and welfare of the people as well as for the armed struggle against the Dutch colonization. Knowing the grave consequence of zakat fund to its authority, the practice did not last long because the Dutch administration created effective control of zakat institutions. The political aim of the Dutch control over zakat was to take a financial source away from Indonesian Muslims and weaken the struggle against the colonization. ${ }^{22}$

Modern zakat management in Indonesia began in the early 20th century. Muhammadiyah, which is the second largest socio-religious organization, created a national zakat institution. The function of this institution was to be an intermediary institution that collected zakat from payers to the eight entitlement groups specified in the Qur'an.

19 Abu N. M. Wahid, "The Economic Implications of Zakah," Contemporary Review, Issue 1440 (January 1986), p. 10-13.

${ }^{20}$ Habib Ahmed, Role of Zakah and Awqaf in Poverty Alleviation, Occassional Paper, (Jeddah: IRTI, 2004), p. 28

${ }^{21}$ R. Djatnika, Tanah Wakaf (Surabaya: Al-Ikhlas, 1982).

22 A. Salim, The shift in Zakat Practice in Indonesia: From Piety to an Islamic Socio Political Economic System (Chiang Mai: Silkworm books, 2008). 
After Indonesia proclaimed its independence 1945, zakat management continued on a local community basis. There was no coordination nor mutual programs established to link one province to another for zakat collection and distribution.

Involvement of the state in managing zakat was still unclear in early Indonesian Government. During the Old Order period, Government Regulation and Regulation of the Minister of Religious Affairs did not assign zakat matters to the Ministry. ${ }^{23}$ It was only in 1968 that the President Soeharto of the New Order officially instructed three high military officers to establish an organizational apparatus for the nationwide zakat collection. Presidential Decree No. 07/PRIN/10/1968 gave impetus to incorporating the zakat affairs into the responsibilities of the state. Later some governors established a semi-autonomous zakat agency, called BAZIS (Badan Amil Zakat Infaq dan Sadaqah, lit: the Office for Management of zakat and charity). ${ }^{24}$ However, since its limited authority and resources, the establishment of BAZIS did not invalidate traditional method of zakat payment. Beside the BAZIS and the traditional system of zakat payment, which still continues at that era, a different initiative of zakat collection and distribution had also flourished through Islamic social and educational organizations. Many of these organizations were branches of national Islamic organizations such as Muhammadiyah or Nahdatul Ulama. They worked in a local area and were more oriented to their communities in using zakat funds. ${ }^{25}$ In addition, private zakat institutions, such as Dompet Dhuafa and YDSF (Yayasan Dana Sosial alFalab), also flourished along with the global phenomena of Islamic economy and revitalization of Islamic awareness starting the 1970s onward. Apparently, the blockage of political channel during Soeharto's presidency had forced Muslims to spend their energy in other similarly important programs, that is economic empowerment for fellow Muslims.

After the fall of Soeharto regime, zakat management, which was more privately managed, became more institutionalized in the form of greater government involvement. This involvement is in terms of

23 Deliar Noer, Administration of Islam in Indonesia (Ithaca, NY: Cornell Modern Indonesia Project, Southeast Asia Program, Cornell University, 1978),

${ }^{24}$ Abdullah, "Zakat Collection", pp. 51, 80.

25 Ibid., p. 54. 
regulatory framework and establishment of semi-autonomous body of zakat management. Based on the Law of Zakat Number 38 year 1999 there are two formal zakat institutions in Indonesia. The statesupported Zakat Collecting Board (BAZ or Badan Amil Zakat) and the privately run institution of National Zakat Collectors (LAZ or Lembaga Amil Zakat). LAZ has over 20 regional offices and only 18 major national-category offices. Of these $18 \mathrm{LAZ}$ offices, five are considered to have the largest overall roles in society, along with BAZ as the sixth largest agency. This has shown that the enthusiasm to practice Islamic teaching related with zakat management has been increased.

\section{The Politics of Non Governmental Zakat Institution Under The Law of Zakat No. 38 Year 1999}

Law of Zakat Management No. 38/1999 was enacted by President B. J. Habibie who succeeded President Soeharto in 1998. Zakat Act No 38/1999 promised to enhance direction and accountability to zakat collector agencies in Indonesia. The Law covered both the semigovernmental collector agencies known as Badan Amil Zakat (abbreviated as BAZ) and the nongovernmental collector agencies known as Lembaga Amil Zakat (abbreviated as LAZ). Both BAZ and LAZ have the same functions: to collect, distribute, and utilize zakat proceeds efficiently. ${ }^{26}$

Law of Zakat Management No. 38/1999 required balance auditing and annual reports to the government, and encourages public disclosure. Zakat Act No. 38/1999 generally regulates the institutions that manage zakat, but it does not make zakat payments obligatory. The state takes a neutral position with regard to the obligatory of zakat in Indonesia. This became the main weakness of this Act. According to Alfitri there could be three reasons for this weakness. First, cognizant of its "secular" stance, perhaps the state wanted to avoid getting involved in defining religious tenets, such as the details of zakat, and enforcing them. Second, the state may have expected details of zakat implementation to be worked out through lower-level regulatory frameworks and their decrees, such as the Minister of Religious Affairs' Decisions. And third, the state simply may not have

${ }^{26}$ Zakat Act No 38/1999 article 8. 
been ready in term of resources and institutional preparation to introduce a full-scale program for zakat management. ${ }^{27}$

Alfitri also identified two main debates on this Act. The first concerns tax deductions. This has been solved by Governmental Decision that zakat paid to BAZ or official LAZ may be subtracted from the gross income of a taxpaying legal body or from the net income of a personal taxpayer up to $2.5 \%$. The second relates to self regulatory zakat management organization. Law No 38/1999 provided some legal basis for zakat management and its institution in Indonesia. It is insufficient, however, without an organizational, accountabilityenforcing structure as well. The adoption of such a structure is indispensable, especially because Law No. 38/1999 and Decision of Minister of Religious Affairs No. 581/1999 do not adequately provide for a body to supervise and regulate the nongovernmental LAZ. Both regulations focus more on the structure and the organization of the BAZ. As a consequence, conflicts of interest or overlapping programs can occur among LAZ.

However, despite all the controversy and debate that accompanies the Law No. 38 Year 1999, after the enactment of the Act there are two major things that greatly influence the history of Islam Indonesia in managing social fund, mainly in zakat and other charitable funds. It was the end of the government exclusive authority in managing zakat, which as mentioned previously indeed is an absolute right and obligation of Umara (government) in Islam. The law sanctioned the handing over of the authority to manage zakat fund to the part of community. The fact that the existence and success of private zakat management institutions preceded the enactment of Law No. 38/1999 also the reason for this arrangement. Both government-backed BAZ and privately initiated LAZ are the same and parallel position before the law. Both have the same authority and role in collecting and distributing of zakat funds for Muslim community in Indonesia.

However, the law does not clarify the roles and functions of BAZ and LAZ in terms of coordination and supervision. This had caused confusion because very often both the Government agency (BAZ) and Community initiative ( LAZ) are operational in the same area. They 'compete' to win muzakeki (zakat payer). As the competition creates unhealthy situation, the government issued a new Law on Zakat

${ }^{27}$ Alfitri, "The Law of Zakat Management and Non-Governmental Zakat Collectors in Indonesia". 
management i.e. the Act No. 23 of 2011 on zakat management to replace the previous Act of No. 38/1999.

\section{The Politics of Non-Governmental Zakat Institution Under The Law of Zakat No. 23 Year 2011}

Zakat management has undergone significant change since the enactment of Act No. 23 of 2011. This new Act mandated a stronger integration of zakat management in the country. According to the Act, the zakat institution is divided in two: (i) government board of zakat and (ii) private zakat institutions. The former is known as BAZNAS or the National Board of Zakat, and the latter is known as LAZ. BAZNAS was given a mandate to lead the integration process and to coordinate all other zakat institutions comprising BAZNAS at the Provincial and City/Regency levels and LAZ.

However, the enactment of Law No 23/2011 on zakat management has caused controversy during the 6th Zakat Forum (FOZ) national congress held in Semarang, Central Java, from April 17 to 19,2012 . According to this forum many of the articles in the law were not clear and capable of multiple interpretations and thus could create problems during implementation. For instance, article 38 on zakat management by mosques, associations and Islamic boarding schools (pesantren) requires registration at the BAZNAS (semigovernmental zakat management). Yet, there is no detailed explanation on how this should be implemented. ${ }^{28}$

The zakat Law No 23/2011 has stipulated that zakat management is the authority of the government and the public is only allowed to participate with a government authorization. It also stipulates that alms management be carried out by BAZNAS operating hierarchically from the central to regional levels. This stipulation seemed to limit the number of zakat-management organizations.

The debate on zakat Law No 23/2011 has driven FOZ to consider a judicial review some articles in the Act to Indonesian Constitutional Court. ${ }^{29}$ The related articles reviewed in the Constitutional Court are listed in the table below:

\footnotetext{
28 Ainur Rohmah, "Law On Alms Causes Controversy," retrieved from http://www. thejakartapost.com/news/2012/04/20/law-alms-causes-controversy.html.

${ }^{29}$ Irman Abdurrahman, et.al., "Satu zakat Seribu Amil", retrieved from http://m.sindoweekly-magz.com/artikel/21/22/-25-juli-7-agustus-2013/mainreview/323/satu-zakat-seribu-amil
} 
Table 1: Articles that be Reviewed in the Constitutional Court

\begin{tabular}{|c|c|c|}
\hline Article & Substance & Problems \\
\hline $\begin{array}{l}\text { Number } \\
5,6 \text {, and } 7\end{array}$ & $\begin{array}{l}\text { BAZNAS is the only authorized } \\
\text { agency to manage the national } \\
\text { zakat. } \\
\text { BAZNAS accountable to the } \\
\text { president through the minister. }\end{array}$ & $\begin{array}{l}\text { It is centralized management } \\
\text { of zakat in the hands of the } \\
\text { government. }\end{array}$ \\
\hline $\begin{array}{l}\text { Number } \\
38\end{array}$ & $\begin{array}{l}\text { Anyone is forbidden to } \\
\text { deliberately act as amil (collector } \\
\text { and distributor) of zakat without } \\
\text { the authorities' permission. }\end{array}$ & $\begin{array}{l}\text { It is criminalization of Amil } \\
\text { zakat who has no } \\
\text { authorization even though } \\
\text { they earn the trust of society. }\end{array}$ \\
\hline $\begin{array}{l}\text { Number } \\
17\end{array}$ & $\begin{array}{l}\text { To assist BAZNAS in } \\
\text { organizing charity, the } \\
\text { community may build LAZ. }\end{array}$ & $\begin{array}{l}\text { It puts LAZ privately formed } \\
\text { by Muslim society under } \\
\text { BAZNAS auspices. }\end{array}$ \\
\hline \multirow[t]{2}{*}{$\begin{array}{l}\text { Number } \\
18\end{array}$} & $\begin{array}{l}\text { The establishment of LAZ must } \\
\text { obtain BAZNAS permission. }\end{array}$ & $\begin{array}{l}\text { It puts LAZ privately formed } \\
\text { by Muslim society under } \\
\text { BAZNAS auspices. }\end{array}$ \\
\hline & $\begin{array}{l}\text { LAZ must be legally registered } \\
\text { as Islamic organizations }\end{array}$ & $\begin{array}{l}\text { It is discriminative and will } \\
\text { eliminate existing LAZs } \\
\text { because most of LAZ formed } \\
\text { as foundation. }\end{array}$ \\
\hline $\begin{array}{l}\text { Number } \\
19\end{array}$ & $\begin{array}{l}\text { LAZ is obliged to report to } \\
\text { BAZ. }\end{array}$ & $\begin{array}{l}\text { It puts LAZ privately formed } \\
\text { by Muslim society under } \\
\text { BAZNAS auspices. }\end{array}$ \\
\hline
\end{tabular}

This reality shows that many aspects need to be put in order. At one side, the civil society participation through private zakat management need to be welcomed to strengthen zakat management that are still far from the full potential in mobilizing zakat funds in Indonesia. At other side, government intend to control the zakat management as the government is responsible in zakat management according to basic injunction of Islamic law.

\section{Tension: Unintended Consequence}

Historical fact shows that in general there has been a transformation or a shift in the management practices of the religious obligation of zakat. At the early Islam, zakat was organized by the 
state. ${ }^{30}$ Later, as Islamic empire collapsed, zakat management then shifted to the duty of individuals. This also happened in Indonesia. Zakat has become a practice of charity of individuals in Islamic society. ${ }^{31}$ In this situation, zakat management which had been practiced individually for a long time in Indonesia was a symbol of civil society where big social organizations such as Muhammadiyah and Nahdhatul Ulama play vital role in implementing zakat management in the society.

However, in the development of zakat management process in Indonesia, there was a necessary point where the involvement of the state is needed to ensure zakat implementation meets the requirements of Islamic shari'ah Islam, as well as the standard of good management, and accountability.. At the end, the full potential of Zakat as an Islamic instrument for achieving social welfare and well-being becomes a practical and significance means. In order to implement zakat properly, involvement of the State, the institution of Zakat and Zakat-officials is indispensable. On the other hand, the right of supervising the smooth functioning of the Institution of zakat, of collecting the zakat dues, and of distributing the zakat funds unquestionably vests in the Muslim State. ${ }^{32}$

The state involvement in zakat management began during the New Order Regime under President Soeharto. Government did not intend to formalize Islam or to legalize zakat in Indonesia. However, government intended to modernize zakat and centralize the zakat management in 1968. This effort failed for various reasons; inadequate resources, lack of institutional framework, and unwillingness of Muslim society to associate with the Soeharto regime in their religious practices. Finally, it ended in 1972. On the contrary, the individual philanthropic practices including zakat fitrah and zakat mal become the norm in society. Many informal zakat institutions in mosques and education institutions were built. Many professional institutions for amil of zakat were established by individuals to serve zakat collection and distribution in society.

\footnotetext{
30 Mohammad Akhtar Saeed Siddiqi, Early Development of Zakat Law and Ijtibad (Karachi: Islamic Research Academy, 1983).

31 Amy Singer, "Giving Practices in Islamic Society," Social Research, Vol. 80, Issue 2 (Summer 2013), pp. 341-358.

32 F. G. de Zayas, The Law and Institution of Zakat (Kuala Lumpur: The Other Press, 2003).
} 
The Act Number 38 Year 1999 has played a very vital role in formalization of zakat management in Indonesia. Under the Zakat Management Act Number 38 Year 1999, the private zakat management (LAZ) sprang very rapidly. The practice to establish zakat collection and distribution centers which professionally managed has been accepted as a new approach of governing zakat as a social institution in Indonesia in this era. The fundamental principle of adopting this approach of governing zakat institution is to strengthen zakat collection and distribution by increasing the efficiency and effectiveness of its management and services, and the end benefits of zakat must go to asnaf socio-economic status, especially the poor. To achieve this principle, the institution of zakat should practice best methods in governing collection and distribution of the zakat.

This paper basically agrees with the idea of modernizing and maximising zakat collection and distribution management. This paper also agrees with the idea to control and supervise private zakat management institutions. However, there are some points that this paper disagrees with, i.e. the centralization and the criminalization of zakat management in the new Act of zakat management.

At the article Number 5, 6, and 7 of Act 23/2011, it was stated that BAZNAS is the only authorized agency to manage the national zakat. At the article number 38 of the new Act of Zakat Management No. 23 year 2011, it was stated that "Everybody is forbidden to deliberately act as amil of zakat without the authorities' consent." The centralization and the criminalization of zakat management would potentially decrease the mobilization of zakat funds. According to data in 2008, LAZ has collected 236 billion rupiah through its five biggest offices, while BAZ collected only 16 billion rupiah. ${ }^{33}$ In terms of amount of zakat fund, this has shown that the private run zakat institutions has performed better in mobilizing zakat funds in Indonesia.

The centralization and the criminalization of zakat management under this new law would also potentially decrease the participation of Muslim society in expressing their religious teaching. At this time, many mosques and Islamic education institutions are trusted by the Muslims to redistribute their charity. If centralization and criminalization are implemented, this would potentially reduce the

${ }^{33}$ Beik, "Economic Estimation and Determinations of Zakat Potential in Indonesia", p. 2. 
spaces for society to express their religious choices in paying zakat to more professional institutions or to any institutions they trusted.

At the end, this paper suggests that regulatory initiative which facilitates the modernization of zakat management in the sense of professional management is in need to maximise zakat collection and distribution. However, this modernization effort should not minimize the spaces for civil society to express their religious choices because of the threat of criminalization. Moreover, the participation of nongovernmental actors in zakat management preceded the government initiative in the area. Likewise, the private actors are proven to be more effective in raising more zakat funds. The centralization of Zakat management under the control of BAZ also needs to be revisited because during the last decade Muslim society has been trusting the service of non-governmental zakat management institutions without worrying about the accountability, credibility, and professionalism. It is true that zakat management is responsibility of government, but the solution to rectify this absence should not curtail the existing wellperforming non-governmental zakat institutions.

This paper suggests that the government should put BAZ and LAZ at the same position. Ideally, the role to supervise BAZ and LAZ management should be performed by other authorized body that is established as regulator of zakat management in Indonesia. In addition to supervising function, this regulator of zakat management will regulate the distinction between BAZ and LAZ to minimize the competition between these two zakat institutions and strengthen the cooperation and the coordination between BAZ and LAZ.

\section{Conclusion}

The main objective of Zakat Management Act Number 23 Year 2011 is to realize social welfare through zakat funds mobilizing. The Zakat Management Act is also a response to the increasing number of zakat management institutions in Indonesia. This Zakat Management Act is projected to have clear impact towards well-performed, professional and accountable zakat management system in Indonesia. However, the modernization of zakat management under the Act Number Number 23 Year 2011 still leaves some debates. A lot number of traditional amil of zakat can be penalized if they are included as "unauthorized" zakat institutions. The centralization of zakat management as a part of government responsibility is also problematic because BAZ still cannot perform well compared to privately managed 
institutions for various reasons. As a result, it is not yet become the central of zakat management in Indonesia.

This paper argues that the zakat management as stipulated by the Act 23/2011 needs to be revisited to sustain and improve nongovernmental zakat management institutions which have been serving Muslims when the government was absent. The people choices in determining which zakat institutions they trust to manage their zakat funds as an expression of their religiosity need to be preserved. Private zakat sector proves to be more active and creative in mobilizing zakat funds. The answer for this problem is building the regulator body for zakat management in Indonesia. This regulator body should effectively regulate $B A Z$ and $L A Z$. []

\section{References}

\section{Books and Articles}

Ainur Rohmah. "Law On Alms Causes Controversy." retrieved from http://www.thejakartapost.com/news/2012/04/20/law-almscauses-controversy.html.

Alfitri. "The Law of Zakat Management and Non-Governmental Zakat Collectors in Indonesia." The International Journal of Not-forProfit Law, Volume 8, Issue 2 (November 2005).

Al-Qaradawi, Yusuf. Fiqh az-Zakah. Beirut: Mu`assasat al-Risalah, 1997.

Ariff, Mohammed. "Introduction." in Mohamed Ariff (ed.). Islam and the Economic Development of Southeast Asia: The Islamic Voluntary Sector in Southeast Asia. Singapore: Institute of Southeast Asian Studies, 1991.

Beik, Irfan Syauqi, et.al. "Economic Estimation and Determinations of Zakat Potential in Indonesia." IRTI Working Paper Series, 09 (October 2012).

Djatnika, R. Tanah Wakaf. Surabaya: Al-Ikhlas, 1982.

Doa, M.D. Menggagas Pengelolaan Zakat oleh Negara. (Jakarta: Nuansa Madani, 2005.

Effendy, Bahtiar. Islam and the State in Indonesia. Singapore: Institute of Southeast Asian Studies, 2003.

Gambling, T. E., and R. A. A. Karim. "Islamic and social accounting." Journal of Business Finance \& Accounting, 13, 1 (1986). 
Godfrey, J. M. and Chalmers, K. (eds). Globalisation of accounting standards. Cheltenham, UK: Edward Elgar, 2007.

Hafidhuddin, Didin. Zakat Dalam Perekonomian Modern. Jakarta: Gema Insani, 2002.

Hassan, M. K.. "An Integrated Poverty Alleviation Model Combining Zakat, Awqaf and Microfinance." Paper presented at Seventh International Conference - The Tawhidi Epistemology: Zakat and Waqf Economy, Bangi, Malaysia, 2010.

Irman Abdurrahman, et.al. "Satu zakat Seribut Amil." retrieved from http://m.sindoweekly-magz.com/artikel/21/22/-25-juli-7-agustus-2013/mainreview/323/satu-zakat-seribu-amil

Kozlowski, G.C. "Religious authority, reform, and philanthropy in the contemporary Muslim world." in W.F. Ilchman, S.N. Katz, and E.L. Queen II (eds). Philanthropy in the World's Traditions. Bloomington: Indiana University Press, 1998.

Lessy, Zulkipli. "Zakat (Alms-Giving) Management In Indonesia: Whose Job Should It Be?." La Riba Jurnal Ekonomi Islam, Volume III, No. 1 (Juli 2009).

M. Abdullah and Abdul Quddus Suhaib. "The Impact of Zakat on Social life of Muslim Society." Pakistan Journal of Islamic Research, Vol 8, (2011).

Mannan, M. A. Islamic Economics: Theory and Practices. Cambridge: Hodder and Stroughton, 1986.

Miftah, A.A. "Pembaharuan Zakat Untuk Pengentasan Kemiskinan di Indonesia." Jurnal Innovation, Volume VII, No. 14 (JuliDesember 2008).

Noer, Deliar. Administration of Islam in Indonesia. Ithaca, NY: Cornell Modern Indonesia Project, Southeast Asia Program, Cornell University, 1978.

Qardhawi Y. Spektrum Zakat dalam Membangun Ekonomi Kerakyatan. Jakarta: Media Intelektual, 2005.

Salim, A. The shift in Zakat Practice in Indonesia: From Piety to an Islamic Socio Political Economic System (Chiang Mai: Silkworm books, 2008.

Siddiqi, Mohammad Akkhtar Saeed. Early Development of Zakat Law and Ijtihad. Karachi: Islamic Research Academy, 1983.

Siddiqi, S. A. Public Finance in Islam. Lahore, Pakistan: n.p., 1968.

Singer, Amy. "Giving Practices in Islamic Society." Social Research, Vol. 80, Issue 2 (Summer 2013). 
Sulaiman, M. "The influence of riba and zakat on Islamic accounting." Indonesian Management and Accounting Review, 2, 2 (2003).

T, Khalidi. The Qur'an: A New Translation. New York: Penguin Classics, 2008.

Wahid, Abu N. M. "The Economic Implications of Zakah." Contemporary Review, Issue 1440 (Jan 1986).

Zayas, F. G. de. The Law and Institution of Zakat. Kuala Lumpur: The Other Press, 2003. 